coal to oil process the country seeks self-sufficiency both for oil and petro-

A final chapter is devoted to the history of the Royal Society itself. It is amusing to find that in 1902 and 1905 the Society made a strong case for metrication of weights, measures and coinage in South Africa, an attempt that failed due to pressure exerted in the British Parliament. The Society was 60 years too early.

It is impossible to summarise in any meaningful way the mass of detailed material contained in this volume. To

\section{Historical revisionism}

\section{J. S. Rudwick}

The Making of Geology: Earth Science in Britain, 1660-1815. By Roy Porter. Pp. 288 (Cambridge University: London, Cambridge and New York, 1977.) $£ 8.95$.

Most Earth scientists are conscious of the great conceptual integration that plate tectonic theory has brought to their science in the past two decades. In retrospect, the immediately preceding period seems like a time of relative stagnation or, at best, of several disparate disciplines evolving in relative isolation.

This situation is not unlike an earlier period, to which historically conscious geologists often look back to find the origins of Earth science as a whole In doing so, however, they generally adopt an historical interpretation that was itself a product of that period. The scientists who first gave 'geology' its institutional and cognitive identity in the early nineteenth century looked back to the eighteenth and late seventeenth centuries as a period of benighted obscurantism or fanciful speculation, relieved only by a few isolated chemicals.

anyone with an interest in South Africa or in the historical concept of how a country can develop scientifically the book is a must. The Royal Society of South Africa is to be congratulated in seeking to put together for the first time the fascinating story of the growth and discoveries of science in southern Africa. Into an atmosphere of political gloom and frustration it injects a note of human achievement and cheer.

K. L. Manchester is Professor of Biochemistry at the University of the Witwatersrand, Johannesburg, South Africa.

pioneers or forerunners of their own approach.

This is the interpretation that $\mathrm{Dr}$ Porter has set out to demythologise. His book is a conscious piece of historical revisionism, yet in no sense is it a facile exercise in debunking. His starting point is the striking discrepancy between the negative evaluation that nineteenth-century geologists gave to the work of their predecessors, and the actual content and scope of that work. The latter is reconstructed by historical analysis of an impressive array of published books and articles, unpublished field notebooks and correspondence, and other material, illustrated by often fascinating quotations. Dr Porter suggests, in my opinion persuasively, that early nineteenthcentury geologists rejected or disowned the past history of their subject, because they felt they had successfully constructed a self-sustaining social enterprise with a new research programme of unlimited potentialitiessignificantly, the very word 'geology' only came into general use at that time. They contrasted this with the relatively undirected and even confused activities of their predecessors. Failing to see how these activities had been an indispensable precondition for their own work, they exaggerated the contrast into an almost total discontinuity.

Making is the key word in Dr Porter's title and in his interpretation.
Although the Earth was in an obvious sense always 'there' to be studied, the body of theoretical ideas and practical techniques that characterised the new science of geology was constructed out of the choices and decisions of individuals and groups in specific historical circumstances. To put it another way, the manifest heuristic success and cumulative character of the mature science of geology since the early nineteenth century is a historical phenomenon that calls for explanation, just as much as the 'failure' of earlier generations to create such a selfsustaining enterprise.

Dr Porter's approach is one in which the traditional dichotomy between 'internalist' and 'externalist' history of science is shown up in all its sterility. It is pointless to trace the growth of a community of like-minded 'geologists', or the reasons why that group developed when and how it did, without analysing the theories and techniques to which their likemindedness was directed; but the converse-the style of traditional 'internalist' history of science-is equally futile. Dr Porter succeeds admirably in blending context and content into a single integrated interpretation.

This book is not, and does not claim to be, a definitive or exhaustive description of all the research that was carried out during the period 1660 1815, even within Britain. It is a suggestive outline of a new way of looking at the early history of the earth sciences. The first appearance of a self-conscious science of geology is not seen as a product of an intrinsic progressiveness of knowledge or of the genius of a few pioneers--interestingly, the Scottish natural philosopher, James Hutton, still sometimes called 'the founder of modern geology', is shown to have been somewhat isolated from the mainstream development of the science. Instead, the emphasis is on the purposeful construction of an integrated discipline with clearly defined methods and-at first-quite narrowly limited cognitive aims; and this construction is seen as the work of individuals and groups working in specific circumstances that constrained the social forms in which their activity was embodied.

The geology that had thus been 'made' by the early nineteenth century is recognisably continuous with the earth science of today, even after its most recent 'revolution'. Dr Porter's account of this construction can be warmly recommended to all Earth scientists who are interested in the foundations of their science.

हี่

M. J. S. Rudwick is Professor of the History of Science at the Free University, Amsterdam, The Netherlands. 